\title{
ANALYSIS THE EFFECT OF COMPENSATION, MOTIVATION, AND JOB SATISFACTION ON EMPLOYEE PERFORMANCE IN CV. CITRA MULYA PERKASA TANGGULANGIN SIDOARJO
}

\author{
ayudevy10@gmail.com¹, hermien.tridayanti@narotama.ac.id²,muchamad.arif@narotama.ac.id
}

Ayu Devy Rustianingtyas ${ }^{1} \cdot$ Hermien Tridayanti ${ }^{2}$, Mochammad Arif $^{3}$

Departement or Management, Faculty Economics and Business, Narotama University, J1. Arief Rahman Hakim No. 51, Surabaya Indonesia ${ }^{1,2,3}$

\begin{abstract}
This study aims to analyze compensation, motivation, and job satisfaction on CV. Citra Mulya Perkasa. The samples in this study are Owners, General Managers, and employees. Techniques for collecting data on interviews, observation and documentation. This study uses qualitative data analysis which consists of data reduction, presentation of data and conclusions and the validity test of the data, namely triangulation techniques. The conclusion of this study is to provide satisfaction that is rich in assistance and incentives. In addition, employees also expect to be given motivation from the leadership so as to increase the results of employee achievement. Therefore, employees will get satisfaction in working at CV. Citra Mulya Perkasa.
\end{abstract}

Keywords : Compensation, Motivation, Job Satisfaction, and Employee Performance

\section{INTRODUCTION}

According to (Dessler, 2015) Human resource management for the process of obtaining, training, assessing, and compensating employees and to manage labor relations, health and safety, as well as matters relating to welfare. Because of the importance of the role of HR and the achievement of organizational goals, HRM must pay attention to several aspects such as important aspects of staffing, training, development, motivation and maintenance.

According to (Hasibuan, 2017) Compensation is all income in the form of money, direct or indirect goods received by employees as a reward for services provided to the company. The establishment of effective compensation systems is an important part of human resource management because it helps attract and retain talented jobs. For organizations / companies, compensation has an important meaning because compensation reflects the organization's efforts in maintaining and improving the welfare of its employees. Compensation is also given by the company as an effort to achieve the success of the company's strategy. The application of compensation programs is very important to pay attention to seriously because compensation can increase and decrease performance, employee motivation and job satisfaction.

According to (Priansa, 2014) Motivation has an influence on learning behavior of students, namely motivation encourages increased enthusiasm and perseverance in learning. Motivation of employee work in a company can be considered simple and can also be a complex problem, because basically humans are very easy to be motivated by giving what they want. And sometimes this work motivation problem can turn out to be difficult in determining the reward where what is considered important for the company because something important that you want to give to the employee who wants to be motivated is not necessarily important or good for that person.

In (Robbins \& Judge, 2015) stated that job satisfaction is a general attitude towards one's work as the difference between the amount of rewards received by workers and the amount of rewards that are believed to be received. This attitude is reflected by work morale, discipline and work performance. Job satisfaction is enjoyed in work, outside of work, and a combination of in and outside work Job satisfaction is basically something that is individual. Each individual has a different level of satisfaction according to the value system that applies to him. The higher the assessment of activities that are felt in accordance with the wishes of individuals, the higher satisfaction with these activities.

Seeing some of these problems which are very important for companies in carrying out each of their work activities so that they can achieve the desired company goals, here the author sets the object of his research on the CV. Citra Mulya Perkasa, which is one of the industrial companies located on the highway Kludan No. 31A Tanggulangin, Sidoarjo, East Java which has been operating since the beginning in the field of producing leather bags. 
Compensation is very important for employees of CV Citra Mulya Perkasa, because the amount of compensation is a measure of the value of the work of the employee itself. We recommend that the size of compensation can affect the work, motivation, and job satisfaction of employees.

Based on the description above, the authors are interested in conducting a study with the title "Analysis of the Effects of Compensation, Motivation, and Job Satisfaction on Employee Performance at CV. Citra Mulya Perkasa ". is

Based on the description of the background described earlier, the formulation of the problem in this study

1. How is the compensation received by employees of CV. Citra Mulya Perkasa?

2. How work motivation is given to employees of CV. Citra Mulya Perkasa?

3. What is the job satisfaction of CV employees. Citra Mulya Perkasa?

4. How is the performance of employees at CV. Citra Mulya Perkasa?

\section{RESEARCH FLOW}

\section{METHODOLOGY}

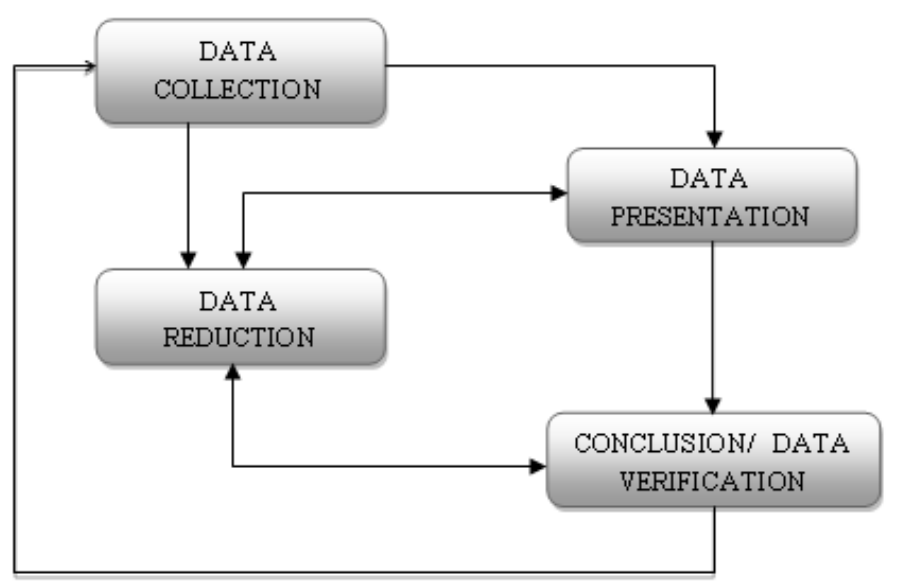

Image: Interactive Analysis Scheme

Source: (Sutopo, 2002)

This study uses a qualitative descriptive research method. Data collected takes the form of words or images rather than numbers. Qualitative research does not use the term population, but by (Sugiyono, 2009) the dynamism of social situations or social situations which consist of three elements, namely: place, actor, and activity which interact synergistically. The sample in qualitative research is not called a respondent, but as an informant or resource person in the study. Informants who were the sources of primary data collection in the company, including the Owner, General Manager, and two employees themselves. Information and data obtained from the informant can then be used to assist researchers in using triangulation techniques.

Data collection techniques are techniques or ways that are used to collect data. The method designates a method so that it can be shown using questionnaires, interviews, observations, tests, documentation and so on. It is very important to pay attention to data collection techniques that will be used as data collection tools. Due to the success or failure of a study depends on objective data.

There are three qualitative data analysis techniques, namely data reduction, data presentation and conclusion drawing. This process continues throughout the research, even before the data is actually collected.

1. Data Reduction

Data reduction is one of the qualitative data analysis techniques. Data reduction is a form of analysis that sharpens, classifies, directs, removes unnecessary and organizes data in such a way that final conclusions can be taken.

\section{Presentation of Data}

Data presentation is one of the qualitative data analysis techniques. Presentation of data is an activity when a set of information is compiled, thus giving a possibility of conclusions.

\section{Withdrawal Conclusion}

Withdrawal of conclusions is one of the qualitative data analysis techniques. Drawing conclusions is the result of analysis that can be used to take action. 


\section{RESULT AND DISCUSSION}

Based on the results of interviews that researchers did with, General Manager, and employees, the researcher can analyze the effect of compensation, motivation, and employee job satisfaction on CV. Citra Mulya Perkasa, which includes:

\section{Owner}

Another important thing to note in reviewing the analysis of the effect of compensation, motivation, and job satisfaction on employee performance. The speaker said that:

"Factors that affect the size of compensation at CV. Citra Mulya Perkasa is the most important is from the performance of the employee itself, the better the performance, the greater the compensation he gets. The form of compensation provided is of course salary / wages as well as providing incentives for employees for their performance to improve employee welfare. The relationship between compensation rates and employee performance has a very close relationship, because compensation is based on the performance of employees in the company environment."

As for other factors such as work motivation also play an important role in employee performance, the speaker said that:

"The way to increase work motivation for employees is the most basic way by strengthening brotherhood among employees and providing rewards / rewards and bonuses for their performance. Motivation is given by instilling in them togetherness between employees with each other and giving rewards / bonuses for the performance they feel. "

Furthermore, the researchers asked the question of how to develop the HR process, the informant said:

"The HR development process is by providing training related to the development of the company in the future in accordance with their respective fields."

\section{General Manager}

Researchers ask questions to the General Manager informants relating to matters that affect employees, the informant said that:

"What influences it is the way we treat employees with a family system and of course by providing appropriate wages / salaries, with the hope that employees can work better."

Next the researcher asks another question about giving motivation to employees, the narrator explains that:

"How to increase employee motivation by providing appropriate incentives and needs that employees want and material that I provide such as ways of service regarding customer satisfaction. The obstacles to implementing it are like changing the mindset of the employee that is considered difficult. To maintain that motivation such as providing motivation that is in accordance with the employee's mindset, providing comfort in the quality of work, and often providing motivation during meetings. "

In addition, researchers also asked other questions related to providing compensation to employees and measuring employee job satisfaction, the resource person explained that:

"The compensation received by employees in terms of salary I think is enough. In addition to salaries and bonuses, the company also provides holiday allowances, holds family gatherings every year, and provides basic food items in the form of rice every month with the aim of prospering employees on CV. Citra Mulya Perkasa. "

\section{Employees}

In addition, the researcher also asked questions to company employees which were also related to the effect of compensation and employee job satisfaction, the speaker said that:

"What is needed by employees at CV. Citra Mulya Perkasa to increase satisfaction in its work such as adequate facilities and equal salaries. For the provision of compensation that has been given by the company, it is considered sufficient in accordance with the work that has been carried out. "

Another source also said the same thing, saying that:

"What is needed by employees is a good level of cooperation between one employee and another employee, as well as several adequate facilities to support the comfort of employees and customers who are visiting CV. Citra Mulya Perkasa. For the provision of compensation it is considered sufficient because the compensation given by the company is in accordance with the work received and has been agreed upon between the employee and the leader when the initial start to work. "

The researcher also asked other questions to the two speakers about giving work motivation obtained from the leadership, the speaker said that: 
"The boss has provided the work motivation needed by the employees, but it needs to be maximized again for the company's affairs given to employees. Motivation has been given as well as passion in work, work evaluation, and innovation. But I have not felt satisfied with giving motivation from superiors because the motivation is only few and rarely delivered. "

Other sources said that:

"Providing work motivation by the leadership of the company has been given but needs to be improved and improved for those who are lacking, in terms of providing examples of how to serve customers as desired by the company's leadership. In addition, needed and desired motivation such as motivation in work, about improving the rules that have been given so far in work that has been applied equally to all employees without exception."

\section{CONCLUSION}

Based on the results of qualitative research with observation, interview and documentation techniques carried out at CV. Citra Mulya Perkasa Tanggulangin Subdistrict Sidoarjo Regency regarding Analysis of the Effects of Compensation, Motivation, and Job Satisfaction on Employee Performance can be taken some conclusions. The conclusion is presented as follows:

1. Giving compensation is very influential for employees at CV. Citra Mulya Perkasa because by providing appropriate and appropriate compensation will have an impact on the employee's performance results. This is shown in the results of the interview to the Owner, General Manager, and two employees. The results obtained from the interview are that compensation received by employees is in accordance with the results of their performance.

2. Giving motivation to employees at CV. Citra Mulya Perkasa felt it was not according to the employee itself. Where according to them the provision of motivation is one of the important elements in improving the quality of their performance that affects the progress of the company.

\section{a. Suggestion}

In a study, a researcher must be able to provide something useful for the development of science, institutions or institutions and various parties related to this research. The suggestions that the researcher gave after examining this problem were:

1. Giving motivation from the leadership is very necessary for employees of CV. Citra Mulya Perkasa because it will have an impact on employee performance results.

2. For further researchers, it is recommended to improve accuracy properly with the completeness of the research data.

\section{REFERENCE}

Dessler, G. (2015). Manajemen Sumber Daya Manusia. In MANAJEMEN SUMBER DAYA MANUSIA (14th ed., p. 3). Salemba Empat.

Hasibuan, M. (2017). Kompensasi. In Manajemen Sumber daya Manusia (Edisi Revi, p. 119). Bumi Aksara.

Priansa, D. (2014). Motivasi. In Perencanaan \& Pengembangan SDM (p. 132). Alfabeta.

Robbins, S., \& Judge, T. (2015). Kepuasan Kerja. In D. Sunardi (Ed.), Perilaku Organisasi (12th ed., p. 170). Salemba Empat.

Sugiyono. (2009). Penelitian Kualitatif. In METODE PENELITIAN (p. 389).

Sutopo. (2002). Proses Penelitian Data. In METODOLOGI PENELITIAN KUALITATIF. 